\title{
Cost overruns and delays in infrastructure projects: the case of Stuttgart 21
}

Bertram I. Steininger, Martin Groth, and Brigitte L. Weber

Working Paper 2020:11

Division of Real Estate Economics and Finance Division of Real Estate Business and Financial Systems Department of Real Estate and Construction Management

School of Architecture and the Built Environment KTH Royal Institute of Technology 


\section{Cost overruns and delays in infrastructure projects: the case of Stuttgart 21}

\section{Bertram I. Steininger}

Division of Real Estate Economics and Finance

Department of Real Estate and Construction Management

Royal Institute of Technology, Stockholm, Sweden

Email: bertram.steininger@abe.kth.se

\section{Martin Groth}

RWTH Aachen University

School of Business and Economics

Templergraben 64

52056 Aachen, Germany

Email: martin.groth@rwth-aachen.de

\section{Birgitte L. Weber}

RWTH Aachen University

School of Business and Economics

Templergraben 64

52056 Aachen, Germany

Email: birgitte.weber@rwth-aachen.de

\section{Abstract:}

Cost overruns and delays in infrastructure projects are not a recent problem. They have systematically occurred globally, in different sectors, and over time. We find that various causes are relevant for the cost overrun and delay of Stuttgart 21 - one of the largest railway projects in Germany in the last 100 years. Among them are project scope changes, geological conditions, high risk-taking propensity, extended implementation, price overshoot, conflict of interests, and lack of citizens' participation. To estimate the costs at an early stage, we apply the reference class forecasting model and thereby forecast the current estimated costs within a confidence interval. To estimate the time, we apply an OLS regression for the different subsections and underestimate or substantially overestimate the duration actually required.

Keywords: Cost overrun, time overrun, infrastructure, reference class forecasting, hyperbolic discounting, principal-agent theory

JEL-codes: H54, O18, R42 


\section{Introduction}

In our globalised world, there is a significant need to travel more frequently and move goods easily and fast. Also in regional terms, the travel and commuting pattern has changed in recent years. More people commute over a longer distance and more often. This trend has led to more and larger infrastructure projects in order to increase mobility and stimulate the economy. The complexity of such mega infrastructure projects increases more than proportionally with their size. At the same time, citizens demand greater participation in the decision-making process of such projects - due both to their part as financial backers with their tax-money and also to their involvement as residents who want to live in a quiet, healthy, and sustainable environment.

In their book 'Megaprojects and Risk: an Anatomy of Ambition' Flyvbjerg et al. (2003a) show that more large-scale infrastructure projects ${ }^{1}$ have been implemented over the last decades but they still suffer from delays, cost overruns, and market shortfalls. They call this 'megaprojects paradox' and instance the UK-France Channel Tunnel project in Europe with an $80 \%$ cost overrun, the Denver International Airport in the USA with a $200 \%$ cost overrun, or the Korean high-speed railway project in Asia with a 217\% cost overrun. They conclude that the reasons for the paradox are that the stakeholders in such projects are incentivised to underestimate costs and environmental impact but overestimate revenues and economic benefits. This is mainly driven by a lack of accountability and inappropriate risk sharing and Flyvbjerg et al. (2003a) recommend reforms in the institutional setting during the decisionmaking process and in institutional accountability.

In this research, we investigate the extent and causes for the cost overrun and delay of the railway project Stuttgart 21; it was the megaproject in Germany which initiated the demand for more democratic participation of the citizens concerned in the decision-making process of infrastructure projects. The European Central Bank (ECB) headquarters in Frankfurt, the Elbphilharmonie Concert Hall in Hamburg, and the Berlin-Brandenburg (BER) Airport are additional examples for cost and time overruns of infrastructure projects which have received extensive media coverage in Germany. Among the finished projects, the ECB was constructed three years later than planned and with a cost overrun of $48 \%$; the Elbphilharmonie was finished seven years later and the cost mushroomed with an overrun of $1025 \%$. Berlin-

$1 \quad$ Megaprojects/Large-scale projects are often infrastructure projects that cost more than USD 1 billion (bn.) but also projects in other sectors such as the defence or information and communications technology (ICT) exceed this amount of money. 
Brandenburg (BER) and Stuttgart 21 are still unfinished. Since Stuttgart 21 was launched in April 1994, it has repeatedly been subject to changes regarding the total costs and the completion date. At the moment, the opening is planned for 2025 - 6 years later than planned, and the cost overrun so far is around $228 \%$.

These overruns are not recent phenomena and occur cross time and geographical locations. Based on different infrastructure projects (roads, rail, bridges, and tunnels) in different regions, Flyvbjerg (2009) and Cantarelli et al. (2012a) detect a systematic underestimation of costs at the beginning of project planning and no improvements in the estimation process over the last 70-80 years. This result is surprising, as it implies that the usual learning curve effects do not apply. The literature provides a range of different causes and theories for the underlying reasons and suggestions that could help to arrive at more realistic estimates, supporting a more efficient decision-making process at the beginning of a project. We add to this literature by arguing that the short-term orientation of traditional discount functions (exponential function) misrepresent the true contribution of the long-term benefits of infrastructure projects which occur during the later operation period. The hyperbolic discounting function could mitigate this trade-off. All the theoretical explanations from the previous literature are discussed in the context of Stuttgart 21 to identify the main causes of its cost overrun and delay and to be able compare them with other projects. In addition, we use the reference class forecasting model in order to see whether it provides a more realistic estimate of the total costs at an early stage. A different forecast model is applied for the time until completion.

The remainder of this paper is organised as follows: We give an overview of the project Stuttgart 21 in Section 2. Next, we summarise the theoretical explanations for cost and time overruns of railway projects in particular (Section 3) and of infrastructure projects in general (Section 4). These theoretical explanations are discussed in the context of Stuttgart 21 to identify the main causes of its cost overrun and delay (Section 5). To estimate the costs at an early stage, the reference class forecasting model is applied to Stuttgart 21 to see whether it leads to a more realistic estimate (Section 6). The final section gives conclusions and offers recommendations as to how costs and construction times might be estimated more precisely at an early stage. 


\section{Overview of Stuttgart 21}

\subsection{Purpose}

The purpose of the Stuttgart 21 (hereafter referred to as S21) project is to modernise and reorganise the Stuttgart rail node in order to increase the capacity. Stuttgart is the capital of the state Baden-Württemberg and the fifth largest city in Germany; the region has around 2.7 million inhabitants, 1 million employees, and generates an annual GDP of EUR 100 billion (bn. $)^{2}$ It is a centre for the German automobile, engineering, and technology industry with the headquarters of large enterprises (including Daimler AG, Porsche AG, Robert Bosch GmbH) and various SMEs. The project's aims are mainly to optimise the transport infrastructure with greater travel capacity, faster regional and long-distance connections, shorter travel times, and improved travel comfort.

\subsection{Brief technical description}

S21 is embedded in the Stuttgart-Ulm rail project - the largest railway project in the state of Baden-Württemberg for more than 100 years. The Stuttgart-Ulm rail project, in addition to S21, consists of the construction of a new long-distance line NBS Wendlingen-Ulm. Figure 1 illustrates the two sub-projects in Section I (S21) and II (NBS Wendlingen-Ulm) in the Map A. For S21, the total line length is $57 \mathrm{~km}$, of which $33 \mathrm{~km}$ are tunnels and cuttings and $22 \mathrm{~km}$ high-speed tracks. The project incorporates 16 tunnels and cuttings, eight bridges, and four train stations.

>> Insert Figure 1 about here. $\ll<<$

In order to reduce commuting time and to increase the capacity, Stuttgart's main station will be converted from an overground terminus station into an underground through station (see Figure 2). The project S21 comprises seven sub-project sections which are equivalent to the official planning approval procedures (PfA) and are shown in Figure 1, Map B. PfA 1.1 is the valley crossing of the city centre including the new central station and new urban light rail tracks; PfA 1.2 is a $9.5 \mathrm{~km}$ tunnel from the central station to Filder region; PfA 1.3 is an above-ground section from the Filder tunnel to the airport, including a new airport station with a trade fair ground and alterations to two lines; PfA 1.4 is a $10 \mathrm{~km}$ new-build line from Filder region to Wendlingen; PfA 1.5 involves long-distance and regional connections to the central station and refurbishment of commuter train lines; PfA 1.6a is the Eastern section of 
the ring; and PfA 1.6b is a construction on the site of the present freight station in Untertürkheim. ${ }^{3}$

The replacement of the current terminal station (17 tracks) with an underground through station ( 8 tracks) is the core of the urban development project (see Figure 2). The relocation of the station into the ground is challenging due to the ground conditions and the groundwater level. The station itself will have a steep slope (6 metres difference in height within a 400 metre distance, although the guideline value is only 1 metre in 400 metres). Therefore, safety measures are necessary for the trains and passengers (wheel chairs, strollers, etc.). A new underground station consequently requires the construction of numerous tunnels and sets free an area of around one square kilometre of railway tracks in city centre. This land will be developed with parks, residential, and office buildings and will expand the previous city centre by around $40 \%$. The land was bought by the city which uses it for different urban and property development projects (see Table I).

>> Insert Figure 2 about here. $\ll<<$

>> Insert Table I about here. $<<<$

\subsection{Stakeholders}

Besides the citizens of the region, there are seven contract partners on the financing side: Deutsche Bahn AG (hereafter referred to as DB), the federal state of Baden-Württemberg, the city of Stuttgart, the Association of the Greater Stuttgart Region (Verband Region Stuttgart), the Airport Stuttgart, the Federal Ministry of Transport and Digital Infrastructure, and the European Union. These partners can be grouped as purely public authorities (e.g., the state or city) and privately-organised companies (such as DB and the airport), which are fully or mostly owned by public authorities. Since 1996, a subsidiary of DB has been in charge of the realisation of the project. Manfred Leger has led his project company since 2013. He is the fifth manager, with other changes taking place in 2002, 2008, and 2011, showing that the continuity was disjointed in the middle of the project period: the dismissals were unexpected and not planned well in advance.

The involvement of the citizens of the region was low initially, and focused on dissemination 
of information on decisions already made rather than a true participation in the decisionsmaking process. Initially, opinion polls had shown that a majority approved the project, but this changed to a negative attitude between 2005 and 2010. Since 2010, most polls have shown that once again a majority is in favour of this project. After several grassroots movements, the "Action Alliance against Stuttgart 21" was founded in April 2007 and comprised around 15 different NGOs, political parties, and lobby groups. In particular, they criticised the lack of democratic legitimacy and participation, security issues and difficult access for travellers to the new station, high costs, and environmental issues such as endangering of ground water.

\subsection{Political dimension}

In October 2010, the protests against the project had reached a peak with two demonstrations of more than 50,000 participants each. This was preceded a week before by a violent police operation against the occupation of the building site where around 100 demonstrators were seriously injured, which was later investigated by a parliamentary committee of inquiry. The police operations and reactions of the government changed the citizens' perception of how political decisions for such projects should be made and the police action was subsequently ruled to be illegal by the Stuttgart Administrative Court. Protests against the project are still taking place every Monday, although the number of participants is smaller at around 1,000 people on the $500^{\text {th }}$ demonstration in February 2020. Table I gives more details about the timeline of the key events of the project.

S21 has had a nationwide influence on citizens' perceptions of their political participation in the context of large-scale infrastructure projects. Since the peak of the protests against S21, citizens in more cities and regions are demanding political participation in the decision process. Four petitions for a referendum at the city level were rejected between November 2007 and March 2015, since the project's dimensions go beyond the city, but a state-wide referendum was held in October 2011. A majority voted against the exit of financing S21, so the project has continued. Although the referendum failed, dissatisfaction with the political leadership influenced the political structure in the state of Baden-Württemberg, where the conservative parties had ruled since 1952. The political party “Alliance '90/The Greens" (hereafter referred to as the Greens) has achieved its highest voting results in this state (1996: 12.1\%, 2001: 7.7\%, 2006: 11.7\%), gaining momentum during the protests where the Greens played an important role. The party demanded stronger environmental protection and political participation for the project. During the peak of the protests, a Green became Prime Minister 
in Baden-Württemberg in May 2011, the first and only Green prime minister in Germany. The party increased its share of the vote, with $24.1 \%$ in 2011 (second strongest party) and $30.3 \%$ in 2016 (strongest party) in the state-wide election. Furthermore, the city of Stuttgart has been run by a Green Lord Mayor since 2013 (the first Green mayor of a state capital): 24\% voted in 2014 and $26.3 \%$ (strongest party) in 2019 for the Greens in the city parliament election. The Lord Mayor often criticised the lack of transparency regarding S21 which led to a loss of confidence among the citizens, but also committed to the project as "a good thing for the city" and demanded "prompt and quality" completion.

\subsection{Delay and cost overrun}

The opening of S21 is planned for 2025, six years later than planned. Since the project was launched on 18 April 1994, the opening has been moved from 2019 in 2010, and 2021 in 2013. It is remarkable that some 16 years of the 26 years since the project was officially initiated were in the pre-construction phase - the period between the formal decision for the project (1994) and the construction start (2010).

Compared to the original cost estimate, at around EUR 2.5 bn. in 1995, the current estimate is EUR 8.2 bn., indicating a cost overrun of $228 \%$. The initial costs were mainly financed by the sale of land/property and federal funds in 1995. Since the progress of the project was only limited in the following years, the next estimate was in 2007 indicating costs as EUR 2.8 bn. At the same time, the financing shares of all parties involved were fixed for the first time. In March 2009, the different partners signed a financing agreement showing costs of EUR 3.1 bn. In 2011, the costs were raised to EUR 4.5 bn., then to EUR 6.5 bn. in March 2013, and further to EUR 8.2 bn. in January 2018 (see Deutsch Bahn, 1995a; Bundesrepublik Deutschland et al., 2007; Land Baden-Württemberg et al., 2009; Kefer, 2012; Deutsche Bahn, 2018).

\section{Causes and remedies based on international railway projects}

By comparing the research on other railway projects, we find that the problem of cost escalation and delays occurs globally, but the magnitude differs and was reduced in some regions in recent decades. At the end of this chapter, we sum up the most important causes and remedies in other projects. The literature can be divided into case studies of single projects and comparative studies at a country/regional level - mostly in Asia, Europe, and North America. 


\subsection{Case studies}

For the former, Han et al. (2009) analyse the Korean high-speed railway project, where the cost overrun was $217 \%$ (USD 18.4 bn. instead of USD $5.8 \mathrm{bn}$.) and the duration of construction was five years longer than planned (from 7 to 12.5 years). These figures are higher in comparison to other Korean projects. Han et al. (2009) focused on the delay in their research. They identify a specific project section as the main driver which had a delay of four years resulting from deferred site acquisition and redesigns of structures. Since this was the first high-speed railway project in South Korea, the owner's abilities and strategies to manage such a project were limited during the implementation phase. As noted by other researchers (e.g., Kostka and Anzinger, 2016), geological conditions and unexpected underground obstacles caused frequent changes in the project and finally delays. In addition, they observed growing public resistance due to environmental concerns.

Chen et al. (2004) concentrate in their analysis on risk management in the West Rail Project in Hong Kong. They identify that price escalations of raw materials, inaccurate cost budgets, and supplier or subcontractor defaults were major risk factors and recommend that a systematic risk management procedure (including risk management policies and staff) could improve the project management to avoid cost overruns, delays, and quality default in largescale infrastructure projects.

\subsection{Country/Regional studies}

Among the country/regional studies, Morris (1990) was one of the first who systematically analysed cost and time overruns. He finds that railway projects in India suffer from high cost and time overruns. By using 23 medium-and-large railway projects in a study of 133 projects in total in the 1980s, he shows on average a delay of $76 \%$ and a cost overrun of $164 \%$. In comparison to all sectors, the delay in the railway sector is slightly higher (66\%) but the cost overruns are almost double $(82 \%)$. He concludes that these overruns are mostly due to poor project design and implementation, inadequate funding of projects, bureaucratic indecision, and the lack of coordination between enterprises. In fact, the government's interventions mitigated the problems in prioritised sectors (oil and natural gas) but worsened the problem in other sectors (railways, coal, and steel).

Also in a newer data set for India, Singh (2010) finds that the railway sector is characterised by the highest delays and overruns, albeit the latter have decreased since the 1980s. The 122 railway projects in India he analysed have on average a cost overrun of $95 \%$ (83\% of the 
projects have an overrun) and $118 \%$ delay (98\% of the projects have a delay). These figures are higher than for projects in all other sectors which show an average cost overrun of $15 \%$ and a delay of $79 \%$. The probability of an overrun and delay in the railway sector is higher, too - the figure for all sectors is $40 \%$ for costs and $82 \%$ for time. He finds regional differences but richer states have not performed significantly better. Further key findings for India are that delays, size, and the implementation phase are the crucial causes underlying cost overruns: the longer the delays and implementation phase, and the bigger the project, the larger the cost overrun.

Before Flyvbjerg et al. (2003, 2004) analysed a worldwide (20 nations) sample of 258 infrastructure developments (e.g., roads, rail, airports, energy, and ICT), little reliable knowledge was available about the performance of these projects in terms of actual costs, benefits, and risks on an international level. The average cost overrun is $44.7 \%$ for rail and $33.7 \%$ for fixed links (tunnels and bridges); cost overrun is rather the rule than the exception it occurs in $90 \%$ of all projects over all 20 nations in the sample, and has not decreased over the past 70 years. They conclude that costs are systematically underestimated during the decision-making process and that the length of the project-implementation phase is positively linked with cost overruns. In addition, larger projects with bridges and tunnels are more prone to cost escalations. Furthermore, they compare three types of project ownership (private, state-owned enterprise, and other public ownership) and conclude that it is not the type private vs. public - but the accountability that influences the cost escalation. By using a second data set containing 208 projects for roads and rails covering 14 countries and a period of 30 years, Flyvbjerg (2009) finds that actual passenger traffic is $51.4 \%$ lower than estimated. He concludes that the cost-benefit analyses are not realistic since the process incentivises underestimating costs and overestimating benefits. He recommends that the problem may be solved by better methods for estimating (costs, benefits, and risks) and by improved governance. He warns that the rapid increase in stimulus spending in developed countries, the increase in projects in emerging economies, and ICT projects will worsen the overruns and shortfalls.

Cantarelli et al. (2012b) analyse 78 Dutch large-scale transport infrastructure projects. Even though cost overruns are as common as cost underruns in the Netherlands, the higher cost overruns lead to an average overrun of 16.5\%. In line with Morris (1990) and Singh (2010), they find that most of the cost overruns (in terms of both frequency and magnitude) take place in the pre-construction phase and give four possible explanations for this. 1) Since project 
plans become more detailed over time, costs can be better estimated - the overruns reflect early misconceptions. 2) The character of cost estimates are primary and "indicative" during the project development phase and become more detailed and "restrictive" after the start of construction. 3) During the pre-construction phase, cost estimates are too optimistic, characterised by the so-called optimism bias. 4) The lower estimates could be a strategy of the decision-makers to get the project accepted.

On the basis of Flyvbjerg and COWI (2004) assessments of causes of cost overruns in Europe and North America (concept changes, environment, costs, and others), Lee (2008) considers these causes in relation to cost overruns in Korean transport projects and how the overruns can be reduced in project preparation and decision-making. He identifies transport projects for a reference class modelling and calculates an overrun probability distribution; he finds that one of 16 railways projects analysed has of a cost overrun rate of lower than $0 \%$, five projects have a rate of $0-25 \%$ and ten projects a rate of $25-50 \%$. Consequently, no project has a cost overrun greater than $50 \%$. He recommends three remedies to avoid overruns: 1) Introduction of an institutional framework for the implementation of an effective integrated cost management system including appraisal, monitoring, and evaluation; for this, the total project cost must be defined as the life cycle cost and not only the construction cost. 2) Introduction of a system that monitors every phase of a project, focusing on impact analysis and postcompletion evaluation. 3) Introduction of a public information and data system for all project phases. This information can be used by decision-makers and researchers to estimate new project costs realistically.

For Germany, Kostka and Anzinger (2016) compare 170 large infrastructure projects in different sectors which have been finished (119) or were unfinished (51) between 1960 and 2014. They find that projects in the energy and ICT sectors face the highest cost overruns with $126 \%$ and $336 \%$ respectively. The cost overrun in the German railway sector is $30 \%$; subprojects of the railway projects, however, are either much higher at 149\% (tunnels) or lower at $11 \%$ (bridges). They find that the cost overruns are more evident in large projects (of over EUR 500 million) than for medium-sized (from EUR 50 million to EUR 500 million) or small (less than EUR 50 million) projects. They also report the flop ten/top ten projects regarding cost overruns and find that among the flops ICT, buildings, and nuclear reactors are the most common projects; among the top ten projects, which performed better than expected, all are in the building and transportation sector. They explain their results by three factors: governance, geographical differences, and a pioneering risk attitude. Even if public-private partnership 
(PPP) projects vary from non-PPP projects, they conclude that the key for more successful projects is a better risk allocation of additional costs and incentives for sufficient cost control. Since the overruns vary between $15 \%$ and $108 \%$ for different German states as they do for international data, they conclude that specific geographical conditions and the politicaleconomic context influence the overruns. Considering the extreme overruns for nuclear reactors in the past and for ICT projects more recently, they conclude that both types are mostly characterised by a pioneering risk attitude without previous experience. This finding is in line with Han et al. (2009) regarding the Korean high-speed railway project. Since Kostka and Anzinger (2016) identify this problem as the key, they recommend that experience of new technologies has to be better institutionalised and incentives have to be set for public planners.

\subsection{Overview of empirical evidence}

By using Cantarelli et al.'s (2012a) worldwide analysis of 806 projects, we can compare projects in the railway sector internationally. Germany shows almost the same cost overrun average as the worldwide average (34\%), but is worse than North West Europe $(22 \%)^{4}$. In comparison to Kostka and Anzinger's (2016) finding of 30\%, Cantarelli et al.'s (2012a) average is 4 percentage points higher. For tunnels/bridges, Germany has an average cost overrun of $27 \%$ which is lower than the worldwide figure (33\%) and North West Europe (32\%). Cantarelli et al. (2012a) conclude that geographical location and sector type are important for the project performance. The geographical location is a proxy for other characteristics such as the decision-making style, system of governance, or culture in general. For future research on an international dataset such attributes should be directly measured as well as the organisational configuration of projects (such as type of procurement or type of financing) to dig deeper into the differences between countries and sector types.

While large-scale infrastructure projects have several unique characteristics and consequently causal factors, we see that the railway sector often has cost overruns and delays, and it may be the sector with the greatest problems (in a country such as India) or with minor problems (as in Germany). Tunnels and bridges are on average sub-projects of the railway sector and are more prone to cost escalations (see Cantarelli et al., 2012b). In particular, tunnels are exposed to unforeseen risk regarding geological conditions and unexpected underground obstacles. Research is still inconclusive about improvements in estimates over time; Singh (2010) finds $4 \quad$ By comparing with North West Europe, we can roughly adjust for legal, cultural, and
geographical conditions. 
supportive evidence in India, but Flyvbjerg et al. (2003, 2004) conclude there is no perceptible improvement over the last 70 years. The size of the project is often positively linked with cost overruns (e.g. Kostka and Anzinger, 2016) as this aligns with complexity and pioneering projects. Various researchers (e.g. Singh, 2010; Cantarelli et al., 2012b) find that the length of the pre-construction phase is positively linked with cost overruns. However, they do not discuss systematic errors that can arise due to unrealistic assumptions for the financial modelling (i.e. discount function) of costs and benefits over time in their studies.

Cantarelli et al. (2012a) note that the reference class forecasting method (Flyvbjerg and COWI, 2004) achieves accuracy in estimating the actual costs, avoiding optimism bias and strategic misrepresentation (see Section 4.3) at the same time. However, the reference class of comparable projects should differ with geographical location, when forecasting the costs of future rail projects; however, this geographical differentiation is not necessary for roads, bridges, and tunnels.

\section{Theoretical background}

Different studies present a range of explanations for cost and time overruns for infrastructure projects. In their meta-analysis, Cantarelli et al. (2010) provide a comprehensive overview of different theories with both narrow and broader focus ${ }^{5}$. We add to these theories a critique of the financial modelling of cost-benefit analysis at the end of this section.

Cantarelli et al. (2010) identify four different categories of explanatory reasons: technical, economical, psychological and political (see column 1 in Table II). These are then linked to different theories (column 2 in Table II) and corresponding research (column 3 in Table II). The authors assume that more than one explanation and/or theory is responsible for cost and time overruns of an infrastructure project and argue that this pluralistic perspective is more appropriate than a single factor model. In the following, we briefly introduce and comment on the four explanations and most important theories.

>> Insert Table II about here. $\ll<$

\subsection{Technical explanations}

Technical explanations for time and cost overruns include inadequate or incomplete estimation methods (Armstrong, 2001), data sets, or project planning (Faludi, 1973). This also

$5 \quad$ Studies in the narrow sense refer to papers primarily regarding cost overruns. In the broader sense, they refer to project development in general. 
incorporates an increase in price and cost levels, general uncertainty over future events, inadequate organisational structure or errors in planning or decision-making processes. Many studies conclude that these technical explanations explain cost and time overruns. However, the difference between estimated and actual costs would converge to zero in large samples and decrease over time due to learning curve effects and improvements of the estimation methods used if this explanation was correct. In fact, this convergence and improvement cannot be verified by empirical studies (Section 3), so that we conclude that cost underestimations are systematic.

\subsection{Economical explanations}

These approaches can be divided into neoclassical and rational choice theory. According to the former, it is rational to present low costs in order to secure project approval, and accessing project funding if financial resources are scarce. Consequently, there is no incentive for an accurate estimation of the costs (Pickrell, 1992). Based on the rational choice theory, it is economically rational to underestimate the costs in a cost-benefit analysis since it increases the "profit" of an infrastructure project and consequently the likelihood of its realisation (Arrow, 1987; Coleman, 1992). The economical explanation is often linked to psychological (Becker, 1976) and political explanations.

\subsection{Psychological explanations}

Psychological explanations concern distortions of perception by the project management and experts; for example, planning fallacy, optimism bias, and cautious attitudes towards risk (Kahneman and Tversky, 1979a). Optimism bias in project evaluation refers to the phenomenon whereby experts and project management estimate costs too low and benefits too high - not intentionally but due to cognitive distortions amongst people directly involved in the project. Even if this error occurs at the very beginning of a project, it is possible to reduce it both through experience over time and with experienced personnel. This is why the psychological explanation alone is not adequate for explaining recurring overruns over the long run.

\subsection{Political explanations}

Political explanations describe whether estimates are distorted due to political interests or stakeholder interests. There are three broad theories addressing this aspect. 1) According to the Machiavellian theory, data are fraudulently misrepresented or even manipulated in order to take personal advantage (e.g. Byrne and Whiten, 1988). 2) Ethical theories try to capture 
the values, customs, and responsibilities of individuals and groups (Wachs, 1982; LaFollette, 2013). Based on these theories, forecasters are less willing to produce accurate estimates due to their lower ethical conduct or due to a lower level of loyalty and responsibility to their agents. 3) The principal-agent theory, in particular, helps to find a more comprehensive explanation for overruns and errors since it also allows for combining the economical and political explanations. Following this theory, people act strategically and in their self-interest, whereby asymmetric information between principal and agent is deliberately exploited by the agents (Noreen, 1999).

\subsection{Further explanation - discount function of cash flows}

A systematic error can also arise due to a systematic error or unrealistic assumptions for the discount function, or more specifically in the time-weighting of costs and benefits. Typically for infrastructure, large costs occur for a short period at the beginning, but are outweighed by benefits which may be lower but extend for a longer period afterwards.

The classical method of discounting future cash flows equalises the costs and benefits arising over time with the exponential function with a constant time preference rate (aka the discount rate $i$ ) resulting in the following function $(\delta)$ over time $(t): \delta_{t}=\delta^{t}=(1+i)^{-t}$. By using this kind of function, values far in the future (mostly benefits for infrastructure) have a very low weighting; whereas values in the near future (mostly costs for infrastructure) have a high weighting. For example, with a discount rate of $5.6 \%$ p.a., the positive/negative contribution of EUR 1 decreases below 10\% after 39 years and below $1 \%$ after 80 years, respectively (see Figure 3). Thus, values in the distant future are of marginal importance in the traditional net present value calculation after a period of 30 to 40 years $^{6}$, regardless of their actual occurrence. However, current costs/benefits are of great importance. This induces pressure to have or - unfortunately - to present low costs at the beginning of infrastructure projects.

One solution to this marginalisation of future benefits could be the hyperbolic discounting function suggested by Angeletos et al. (2001). The addition of two time preference parameters $(\alpha$ and $\gamma)$ results in a discount factor of $\delta^{t}=(1+\alpha \cdot t)^{-\gamma / \alpha}$. Thereafter, the costs/benefits contribution - using the parameters of Angeletos et al. (2001) for $\alpha$ and $\gamma^{7}$ - only drop below $10 \%$ after an extremely long time (2500 years). This method maps the long-run benefits

\footnotetext{
$6 \quad$ The feasibility study of Stuttgart 21 by Deutschen Bahn (1995b) assumes a period of 45 years in total. However, a significantly shorter period of about 30 years is frequently applied.

$7 \quad$ See Angeletos et al. (2001) for the theoretical foundation and determination of the parameters; $\alpha=4$ and $\gamma=1$.
} 
characterising infrastructure projects better than the exponential function, as the future benefits for the next decades are important. The UK Department of Transport (2011) takes another path for the same goal, mandating a step-by-step decreased discount rate. The initial discount rate drops by 0.5 percentage points to $3.0 \%$ after 30 years and to $2.5 \%$ after 75 years. Although this method is inferior in terms of continuity and of representation of reality, it approximates to the long-term character of infrastructure projects (see Figure 3 for a comparison of all three methods).

>> Insert Figure 3 about here. $\ll<<$

\section{$5 \quad$ Causes for S21}

In the following, we discuss to what extent the previous explanations (Section 4) for cost overruns and delays apply to S21.

\subsection{Changes and long implementation period}

The project scope of S21 has changed over the years of planning and realisation. Initially, only the reorganisation of the main station and the lines directly connected to the station was planned. Later, the new railway section NBS Wendlingen-Ulm also became part of the project (see Figure 1). The German Federal Audit Office (Bundesrechnungshof) concluded that the desired saving of travel and commuting time could only be achieved through integrating the new railway section into the project (Bundesrechnungshof, 2008a).

Furthermore, it criticised the absence of a breakdown of all expected tasks, increasing the likelihood that the original financial projection would increase once those costs were included.

In line with the findings for other railway projects (Cantarelli et al., 2012b; Kostka and Anzinger, 2016), geological conditions and unexpected underground obstacles lead to delays and cost overruns. In particular, the groundwater management for the construction and the stone layer under the new main station caused enormous problems. Furthermore, the preservation of the historical station building incurred additional time and costs.

\subsection{Long implementation period and high risk taking}

Large-scale projects are often characterised by long planning horizons and complex tasks (Flyvbjerg, 2009). The period between the formal approval for the project and the start of construction was extremely long, at almost 16 years (see Table I). As found by Morris (1990), Singh (2010), and Cantarelli et al. (2012b) for other projects, this was an important driver of 
cost overruns and delay for S21.

The applied techniques/technologies (e.g., the extreme slope of the S21 platform) and design (e.g. the underground main station) are often non-standard or even completely new, so that the use of the experience gained in previous projects is limited and an additional cause for the cost overrun of S21. During the early stage, DB considered alternatives for the complex underground station (Deutsche Bahn, 1995a). The first alternative consisted of smaller variations in the underground station (e.g. modified railway routes). The second alternative left the terminus station over the ground, but with modifications and renovations. In the feasibility study of 1995, the cost of this possibility was estimated at EUR $2.1 \mathrm{bn}$. This concept would have been - at least at that point in time - less expensive than converting the old station into an underground station (EUR 2.5 bn.). From an economic perspective, it is not clear why the project planners chose S21. It may rather be an example of the high-risk attitude of engineers/project developers who want to create a landmark building without being responsible for paying the costs - principal-agent theory.

\subsection{Underestimated price increases and opaque cost calculation}

In line with other projects (e.g. Chen et al., 2004), the incorporated increase in price levels (market prices and inflation) over time was either non-existent or too low in comparisons to the historical price trend of construction costs and common inflation. Between 1994 and 1998, DB calculated using price levels as of January 1993. After an update in 2004, this new price level was used until 2009 (Bundesrechnungshof, 2008a). The change in prices for the period between 1998 and 2004 alone were retrospectively estimated at EUR 2.6 bn. Thus, the project management did not apply annual cost increases based on historic data. ${ }^{8}$ Even if the actual costs were updated in the financing plan of March 2009, the possible additional costs were not adjusted and remained at the price levels of 2004 (Land Baden-Württemberg et al., 2009). This adjustment was incorporated in December 2009, causing an increase in the total costs from EUR 3.076 bn. to EUR 4.088 bn. (Kommunikationsbüro Bahnprojekt Stuttgart, 2009).

However, the increase in the construction costs used was unrealistically low with an annual increase of $1.5 \%$ (Bundesrechnungshof, 2008a). Vieregg-Rössler (2008) applied an increase in construction costs of $2 \%$, resulting in a rise in the costs to EUR $6.9 \mathrm{bn}$. The $1.5 \%$ increase was based on the construction cost index for roads in the state Baden-Württemberg, although

$8 \quad$ The construction costs had increased annually between 2004 and 2009 (Statistisches Bundesamt (2013a), production index for civil engineering). 
S21 is a railway project. According to comparison studies on the country level (see Section 3.2), costs differ significantly between roads and railways and are mostly higher for the latter. Consequently, an incorrect reference class was set.

DB was criticised for the non-disclosure and missing information concerning project financing to the public and even project partners. For example, cost savings amounting to EUR 900 million were included in the calculations, although the Federal Railway Authority had not yet given its approval (Kefer, 2010). Holzhey (2010) adds that it is not possible to identify the origin of these potential savings. In addition, a loan granted by the Airport Stuttgart was not part of the financing plan (Isenberg, 2008), even though DB listed this loan among the costs that would arise if the project were to stop (Deutsche Bahn, 2013a).

\subsection{Various stakeholders and no participation of citizens}

S21 has seven different financing partners, each with partly different interests (e.g. DB vs. city) and at least 60 external planning offices have been involved. This has caused many conflicts of interest, in combination with the frequent changes at the top level of the project management (Kefer, 2010). Most important, DB considered stopping the project in 1999, but abandon the option after the city and the federal state threatened to take legal action against this step. In 2013, DB confirmed that it would not have started the project if it was making the decision at that point, but it proceeded with the project because the alternative then was to pay additional costs of EUR 2.0 bn. (Deutsche Bahn, 2013a).

However, most striking was the conflict with the citizens and "Action Alliance against Stuttgart 21" who were against the project in general or demanded higher participation in the decision-making process. Numerous legal procedures regarding environmental or noise protection, demonstrations, petitions, referendum, and the general dissatisfaction with the execution of the construction works changed the political framework in the city and state. At the beginning of the project, the initiating partners underestimated the democratic movement towards more direct involvement and participation by the citizens financing such large-scale infrastructure projects. Also, the reaction of the executive partners to the demand arising for participation was counterproductive. Instead of allowing democratic participation in the decision-making process, they simply informed the citizens about decisions made and increased their "law and order" strategy against protesters. These actions decelerated the process by months or even years (see Section 2.4). 


\section{Reference class forecasting and OLS regression}

\subsection{Previous literature and concept of reference class forecasting}

Research on psychological biases and inconsistencies regarding neoclassical economic theory and the asset class of real estate and infrastructure has been applied to property studies previously. Zillante et al. (2019) apply the prospect theory by running experiments in the framing of land aggregation. They confirm that the effect on the loss side of landowners is stronger than on the gain side, a result driven by the uncertainty in the number of offers coming from a buyer/developer. In the same vein of denying the neoclassical theory is the research about downside risk, since real estate/infrastructure returns are not normally distributed and standard risk measures are therefore inferior to downside risk measures. Among the first for real estate, Sing and Ong (2000) find that applying a lower partial moment optimisation instead of the traditional Markowitz optimization for asset allocation provides more efficient and robust results using real estate data from Singapore. In the same line, Lee et al. (2008) confirm the theoretical advantage of lower partial moment measures within the framework of CAPM, if applying it to the real estate class. They conclude that there is little evidence that the typical strong returns on the high leveraged real estate compensate for the greater systematic risk in Australia. Wurstbauer and Schäfers (2015) move the downside risk measure to the class of infrastructure and test its inflation-hedging characteristic. First, they find that real estate and infrastructure returns have different characteristics since real estate returns are Granger-caused by inflation, whereas infrastructure returns are a cause of inflation. Second, and by using lower partial moments, they find that direct infrastructure investments have the lowest downside risk and consequently the most desirable inflation protection compared to other asset classes (indirect/direct real estate and infrastructure).

With reference class forecasting (RCF), similar past reference projects are used to estimate a distribution function for the outcome of the project to be examined. With their work regarding cognitive optimism bias and prospect theory, Kahneman and Tversky (1979a, 1979b) and Kahneman (1994) provided the basis for RCF. Project developers are prone to cognitive biases; they think in scenarios, are anchored in stale estimations, or extrapolate current trends. Most of all, they tend to be too optimistic (optimism bias). Induced by uncertainties and information asymmetry, forecasts are often biased in their estimations of costs and benefits (overconfidence effect) as well as in the weighting of probabilities of costs and benefits (prospect theory). On the one hand, project stakeholders tend to underweight the probabilities 
of the costs, risks, and duration until completion and on the other hand, to overweight the probabilities of the benefits by focusing on the current project instead of a broader basis of comparable projects (aka the inside view). However, the knowledge of similar projects' results would help to objectify the estimates for the current project and should consequently result in better forecasts (aka the outside view). By using this reference class concept, forecasters are able to eliminate their biased weights of probabilities (prospect theory).

The idea of the outside view is not to forecast events or use influencing factors that may affect the project but rather to place the respective project in a statistical distribution of actual figures (costs, delays, benefits) based on reference projects - the reference class. By using this method, forecasts are more likely accurate and much less likely unrealistic (see Lavallo and Kahneman, 2003). The outside view incorporates the following three steps (for more detail, see Flyvbjerg and COWI, 2004, pp. 8-9).

1) Identification of relevant reference projects:

The challenge of this step is to collect data which are broad enough to be statistically meaningful (e.g. among different regions or countries) but narrow enough to be comparable within the reference class (the type of infrastructure: road vs. rail).

2) Generating a probability distribution for the selected reference class:

Flyvbjerg and COWI (2004) recommend collecting at least ten comparable projects to be able to draw statistically meaningful conclusions.

3) Placing the project of interest at an appropriate point in the distribution:

This step is prone to optimism bias since it relies on an intuitive assessment of the right "point" in the distribution. Thus, we use a point estimate for the mean and a $95 \%$ confidence interval.

Flyvbjerg and COWI (2004) applied RCF to forecast the costs of infrastructure projects and used it in practice for the first time for a local public transport project in Edinburgh in 2004. ${ }^{9}$ In the meantime, several countries (e.g. Australia, Denmark, the United Kingdom, the Netherlands, Switzerland, and South Africa) have implemented different forms of RCF models in their decision process of infrastructure projects.

$9 \quad$ Already three years before, the AACE International (2006) recommended an examination of projects by comparison to estimate costs. 


\subsection{Application to the costs of S21}

The cost overrun for S21 is 228\% - compared to the original cost estimate at around EUR 2.5 bn. in 1995, the current estimate is EUR 8.2 bn. in 2018. This number is high in comparison to other studies in the railway sector (see Section 3.3); the German average is 30\% as presented by Kostka and Anzinger (2016). Also on the international level, we see mostly lower averages. Lee (2008) finds no project which has a cost overrun greater than 50\% in the Korean transport sector but Han et al. (2009) report that the Korean high-speed railway project had a cost overrun of $217 \%$. Flyvbjerg et al. $(2003,2004)$ report an average cost overrun of $44.7 \%$ for his worldwide dataset (20 nations). The average cost overrun in India is high as well; Morris (1990) shows on average of $164 \%$ and Singh (2010) finds an average of $95 \%$. However, almost all of these figures are averages so that we see the need to collect our own reference projects to be able to generate a probability distribution.

We test whether the RCF model based on ten reference projects built by DB in recent years (see Figure 4) gives us a more realistic picture of actual/current costs - this is step 1. All reference projects were constructed in different German states so that we follow Cantarelli $e t$ al.'s (2012a) recommendation that comparable projects should differ by geographical location, when forecasting the costs of railway projects. However, the reference projects have a lower number of tunnels in comparison to S21; this may lead to an underestimation of the costs, as Flyvbjerg et al. $(2003,2004)$ show that larger projects with bridges and tunnels are more prone to cost escalations.

In step 2, we generate the probability distribution. For the reference projects, the actual costs range from EUR 145 million to EUR $6.2 \mathrm{bn}$. with a mean value of EUR $1.5 \mathrm{bn} .{ }^{10}$ The ratios of cost overrun (actual costs/planned costs $-100 \%$ ) range from $0 \%$ to $425 \%$ with a mean value of $157 \%$ and a standard deviation of $128 \%$. Applying these figures on S21 in step 3, results in a mean forecast of EUR $6.4 \mathrm{bn}$. with a lower limit of EUR $4.1 \mathrm{bn}$. and an upper limit of EUR $8.7 \mathrm{bn}$. for the $95 \%$ confidence interval. Even if the mean forecast underestimates the current estimated total costs by EUR 1.8 bn., it lies within the 95\% confidence interval. This means that RCF could help to anticipate the forecast cost overrun for $\mathrm{S} 21$ from the very beginning.

〉> Insert Figure 4 about here. $\ll<<$

$10 \quad$ The RCF was conducted using railway projects based on a report in 2013. During the planning process for S21 since 1995, there would have been different reference projects. Since the forecast error does not change significantly over time, we assume that our data sample leads to a similar result. 


\subsection{Delay of S21}

Since the project was officially introduced in 1994, 26 years have passed, 16 of which were before the start of construction works in 2010. If it meets the currently planned completion date of 2025 - which includes a six year extension. Based on the first estimate in 2010, this is a delay of $67 \% \%$. Compared to Flyvbjerg's (2007) sample, the project duration is an extraordinarily long time, as he refers to railway projects with a duration of 13 years as statistical outliers. Again, Morris (1990) finds a high number for India with a delay of $76 \%$ on average; Singh (2010) reports even on average a delay of 118\% for India. Han et al. (2009) analyse the five years longer than planned period of the Korean high-speed railway project.

When looking at the delay of S21 in more detail, it becomes apparent that the planning process makes up a substantial part of the project's total duration. According to legal requirements, the developer needs to obtain approval in accordance with planning approval procedures (PfA). ${ }^{11}$ Such an approval procedure for railways usually takes several years ${ }^{12}$ and may account for a significant share of the project's total time. The project developer has limited influence over the approval duration, as the procedure is the responsibility of the Federal Railway Authority. To hasten this process, larger projects are split into sub-projects (seven for S21; see Section 2.2); all of which require a PfA to be conducted before construction can start.

For developers, it would be desirable to have an estimated duration for more reliable planning. To close this gap, we try to forecast the time for the seven PfAs not by using a simple RCF ignoring the explanatory factors but by using an OLS regression. To this end, we collect different German railway projects with their characteristics and run an OLS regression in order to forecast the time required for each of the seven S21 PfAs. Since five of the seven are already approved, we can compare our estimate with actual time and evaluate the accuracy of our straightforward method.

\subsubsection{Data and descriptive statistics}

All railway projects used in our analysis have already been approved by the Federal Railway Authority (FRA) and must fulfil the following criteria. The projects are new constructions or

\footnotetext{
11 "The aim is a comprehensive check of the problems arising from interventions in existing material rights and relationships by means of regulation of the relationships between the project developer, the public authorities and private stakeholders" (Eisenbahn-Bundesamt, 2012).

$12 \quad$ For example, a PfA of the new line Nuremberg-Ingolstadt-Munich took 4,960 days (13.6 years) from the submission to the decision (Eisenbahn-Bundesamt, 2010).
} 
extension works, excluding projects which only cover minor works (e.g. slope stabilisation, relocation of the current route, or renovation of buildings).

Referring to other empirical research on explaining cost overruns (e.g. Han et al., 2009), we adopt our forecast model with a set of quantitative and qualitative explanatory variables which may help us to explain the duration of the approval. Other empirical research beyond RCF for forecasting delays is limited. Unfortunately, it is not possible to identify adequate proxies for all theoretical explanations for delays - technical, economical, psychological, and political. The track length of the project is our proxy for the technical aspect, total costs cover the economic perspective, the number of municipalities which are involved and average population density of the surrounding areas are our proxies for the political dimension.

Our dependent variable (duration) measures the days between the submission to the FRA to the final decision. We use two samples for which we are able to obtain a different number of influencing factors, see Table III for more information on our data source. For sample 1 which comprises the highest level of railway projects in Germany, total investment (total costs) is the only explanatory variable. Since data on the financial aspects of each PfA are scare, this limits our observations to 25 . The costs of a project should align with its complexity and are positively linked with duration. The total costs vary from EUR 145 million to EUR 6.172 bn. with a mean of EUR $1.066 \mathrm{bn}$. The descriptive statistics is given in Table III.

For sample 2, we do not have access to the total costs but can rely on other explanatory variables: length of the lines (track length), number of municipalities which are involved (\# municipalities), and average population density of the surrounding areas (population density). Furthermore, we incorporate the location of the FRA office involved, assuming that the staffing (e.g. skills, number of the employees) of an office and the geological conditions in the corresponding area may have an impact on duration. We assume that the longer the length of the railway tracks, the longer the PfA takes. The average length is $8.4 \mathrm{~km}$. In addition, it is likely that the approval lasts longer if more municipalities are involved and if the average population density of these municipalities is higher. On average, 2.4 municipalities are involved which have an average population density of 858 residents per square $\mathrm{km}$.

>> Insert Table III about here. $<<<$ 


\subsubsection{Models and results}

To deal with the skewness of our variables and the decreasing influence of higher magnitudes of the explanatory variables on the dependent variable (duration), we apply a log-log model. The coefficients can be interpreted as the elasticity of the variables regarding duration. We start with the simple model specification M1 for sample 1, where total costs of the total project is the only explanatory variable for the duration. It is given as follows:

$$
\ln (\text { duration })_{i}=\alpha+\beta \ln (\text { total costs })_{i}+\varepsilon_{i}
$$

The results of this model specification are given in Table IV, column M1. As expected, more expensive projects take longer; the duration increases by $0.7 \%$ when total costs increase by $1 \%$ - this finding is significant at the $1 \%$ level. This simple model explains around $65 \%$ of the variation.

For sample 2, we exchange total costs with three alternative explanatory variables (track length, \# municipalities, population density) since these variables are more often available. With this alternative to M1, we increase the number of observations to 64 . The model specification M2 is given as follows:

$$
\ln (\text { duration })_{i}=\alpha+\beta\left(\begin{array}{c}
\ln (\text { track length })_{i} \\
\ln (\# \text { municipalities })_{i} \\
\ln (\text { population density })_{i}
\end{array}\right)+\varepsilon_{i}
$$

With the exception of track length, the coefficients are statistically significant at the 5\% level (see Table IV, column M2). The duration, ceteris paribus, takes longer the more municipalities are affected $(0.4 \%)$ and the denser the population of the affected area $(0.2 \%)$. The correlation between the variables is -0.45 for \# municipalities and population density and +0.73 for \# municipalities and track length. The adjusted $\mathrm{R}^{2}$ is significantly reduced (12\%) in comparison to M1.

In M3, we add to M2 the influence of the location of the FRA office responsible for the approval. This dummy variable has Karlsruhe/Stuttgart as its base since it is responsible for S21. The results (see Table IV) show that Cologne and Munich have longer PfAs in comparison to Karlsruhe/Stuttgart, whereas Erfurt has a shorter period. For example, Munich increases a 
PfA by approximately $51 \%$. This Munich effect could be driven by locational and geological conditions around Munich; e.g., the population density is high. The influence of the remaining locations is not significant at any conventional level. Even if the adjusted $\mathrm{R}^{2}$ is higher (33\%) than in M2, the main explanatory factors (track length, \# municipalities, population density) are not significant at any conventional level.

Thus, we use the coefficients of M1 and M2 for estimating the seven PfAs of S21 in the next step.

>> Insert Table IV about here. $<<<$

\subsubsection{Application to the duration of S21}

Five of the seven S21 sections have already been approved. Only the decisions regarding sections PfA 1.3 "Filder area with access to the airport" and PfA 1.6b "Carriage siding Untertürkheim" are still ongoing. Using the current estimations of total costs of EUR $8.2 \mathrm{bn}$. of S21, M1 provides the duration of 4,326 days (11.9 years) for all PfAs. Specification M2 yields an estimated duration of 1,155 days for PfA 1.3 and 1,383 days for PfA 1.6b, respectively. Table V shows all estimated durations of the two specifications (M1 and M2) for all seven PfAs and compares them with the actual duration.

\section{>> Insert Table V about here. $\ll<<$}

The estimated durations significantly deviate from the actual duration for M1: it overestimates the duration on average, by 2,700 days (7.4 years). The most exact estimation is provided by M2 which underestimates the duration on average with 456 days. The most exact estimation is an overestimation of 33 days for PfA 2.3, whereas the largest deviation can be found for PfA 1.6a with an underestimation of 793 days. In summary, M1 has a better explanatory power but fails to forecast the duration - its accuracy rate is $181 \%$ (difference of durations/actual duration*100\%). M2 provides an accuracy rate of $-27 \%$. Since the data availability, mostly for total costs, is limited and given that further explanatory variables could improve the forecast model, further research is needed into forecasting the duration of PfAs in order to reduce the delays in large-scale infrastructure projects.

\section{Discussion and conclusion}

Since the railway project Stuttgart 21 was launched on 18 April 1994, it has been subject to repeated changes regarding the total costs and the completion date. As of today, the estimated 
costs of this unfinished large-scale infrastructure project are EUR 8.2 billion, and thus $228 \%$ higher than expected in 1995, and the estimated delay is six years.

Several causes and theories (see Cantarelli et al., 2010; Flyvbjerg, 2009) have been identified to justify cost overruns and delays in infrastructure projects in general: technical, economical, psychological, and political. Even though all these approaches individually can help explain errors in the forecasts, the combination of economical and political causes proves to be useful for explaining systematic errors which exist in the long run. This paper contributes to the existing theories by arguing that the short-term orientation of traditional discount functions (exponential function) misrepresents the true contribution of the long-term benefits of infrastructure projects which occur during the operation period. The use of exponential functions may even lead to a strategic underestimation of the short-term costs during the construction period. We believe that the exponential function is inappropriate for long-term projects such as infrastructure and suggest the hyperbolic function as a better tool for the timeweighting of temporally different cash flows.

We extract the relevant causes for cost overruns and delays observed in other research on railway and tunnel/bridge projects in Asia, Europe, and Northern America (e.g. Flyvbjerg, 2009) and identify the following causes for the cost overruns and delay of Stuttgart 21. The project scope changed at the beginning to achieve the promised travel time reduction. The geological conditions for the technically challenging new main stations in the underground are demanding and caused delays. The high-risk-taking approach in favour of the technically more ambitious new station was not driven by economic factors. The technical challenges resulted in an extremely long implementation period (time between project launch and construction start). Fundamental cost calculation considerations (i.e. price increases and inflation) either were not or were only insufficiently incorporated during the planning period. The interests of the various project differ to some extent resulting in conflicts between contrasting views about the future of the project (stop vs. continue). Lastly, the project partners severely underestimated the rising participation movement amongst affected citizens and, in consequence, reacted counterproductively.

We apply a reference class forecast (RCF) model (Flyvbjerg, 2009) for the costs of Stuttgart 21. Our aim is to minimise the unrealistically optimistic estimates during the early stages of projects. Unfortunately, these estimates are often used in the decision-making process. Using ten references, our model forecast costs of EUR 6.4 bn. with an interval between EUR $4.1 \mathrm{bn}$. 
and EUR 8.7 bn. for the $95 \%$ level of confidence. Since the current estimate of EUR $8.2 \mathrm{bn}$. lies within this interval, we see our approach as a good tool to reach closer to the actual costs than relying on the first estimate of the project team. A limitation of this method, however, is the low number of comparable projects which can be used as references.

Inspired by cost estimation models, we try to forecast the duration of planning approval procedures (PfA), since they make up a substantial part of the project's total duration. By using two specifications of an OLS model, we are able to forecast the actual durations of the PfAs of Stuttgart 21 with an accuracy rate of $-27 \%$. Based on the limited research on the time forecast model and our results, we see a need for further research to improve such models.

We deem both aspects - cost and time - to be of practical importance. Straight-forward forecast models can help to reduce the gap between the unrealistic estimates in the planning period and the actual figures in the end. Reliable figures are important in the light of the rising demand for democratic participation in the decision-making process amongst the citizens concerned An even easier approach would be the implantation of the stepwise exponential or discount hyperbolic function to avoid a strategic underestimation of the short-term costs during the planning period. Furthermore, we hope for more research about time forecast models to minimise the risk of delays in large-scale infrastructure projects. Both applied approaches (RCF and OLS) can help to reduce the gap between the unrealistic estimates in the planning period and the actual costs and completion date in the end. 


\section{References}

AACE International (2006), Total Cost Management Framework, Section 7.3, Cost Estimating and Budgeting.

Altshuler, A. and Luberoff, D. (2003), Mega-Projects: The Changing Politics of Urban Public Investment, Brookings Institution: Washington, D.C.

Angeletos, G.-M.; Laibson, D.; Repetto, A.; Tobacman, J. and Weinberg S. (2001), "The hyperbolic consumption model: calibration, simulation, and empirical evaluation", Journal of Economic Perspectives, Vol. 15 No. 3, pp. 47-68

Armstrong, J.S. (2001), Principles of forecasting: a handbook for researchers and practitioners, Kluwer Academic Publishers: Norwell.

Arrow, K.J. (1987), Economic theory and the hypothesis of rationality, The New Palgrave: a dictionary of economics, 2nd edition, pp. 69-75.

Arvan, L. and Leite, A.P.N. (1990), "Cost overruns in long term projects", International Journal of Industrial Organisation, Vol. 8 No. 3, pp. 443-467.

Becker, G.S. (1976), The Economic Approach to Human Behavior, University of Chicago Press: Chicago.

Bruzelius, N.; Flyvbjerg, B. and Rothengatter, W. (2002), "Big decisions, big risks. Improving accountability in mega projects", Transport Policy, Vol. 9 No. 2, pp. 143154.

Bundesrechnungshof (2008), Bericht an den Haushaltsausschuss des Deutschen Bundestages nach $\S 88$ Abs. 2 BHO über die Projekte Stuttgart 21 und die Neubaustrecke Wendlingen-Ulm.

Bundesrepublik Deutschland, Land Baden-Württemberg, Deutsche Bahn AG, Landeshauptstadt Stuttgart und Verband Region Stuttgart (2007), Memorandum of Understanding zur Realisierung der Neubaustrecke Stuttgart-Ulm und des Projekts Stuttgart 21, in: http://www.bmvbs.de/cae/servlet/contentblob/29112/publicationFile/3300/memorandu m-of-understanding.pdf, retrieved 10 November 2019.

Byrne, R.W. and Whiten, A. (1988), Machiavellian Intelligence: Social Expertise and the Evolution of Intellect in Monkeys, Apes, and Humans, Oxford University Press: Clarendon.

Cantarelli, C.C.; Flyvbjerg, B. and Buhl, S.L. (2012a), "Geographical variation in project cost performance: the Netherlands versus worldwide", Journal of Transport Geography, Vol. 24, pp. 324-331.

Cantarelli, C.C.; Flyvbjerg, B.; Molin E. J. E. and van Wee, B. (2010), "Cost overruns in large-scale transportation infrastructure projects: explanations and their theoretical embeddedness", European Journal of Transport and Infrastructure Research, Vol. 10 No. 1, pp. 5-18.

Cantarelli, C.C.; Molin, E.J.; van Wee, B. and Flyvbjerg, B. (2012b), "Characteristics of cost overruns for Dutch transport infrastructure projects and the importance of the decision to build and project phases", Transport Policy, Vol. 22, pp. 49-56.

Chen, H.; Guilin, H.; Poon, S.W. and Ng, F.F. (2004), Cost Risk Management in West Rail Project of Hong Kong, AACE International Transactions, INT.09, Morgantown, 9.19.5 .

Christie, R. and Geis, F. (1970), Studies in Machiavellianism, Academic Press: New York.

Coleman, J.S. (1992), Rational choice theory: advocacy and critique, Sage Publications: Newbury Park. 
Department of Transportation (2011), Transport Appraisal And The Treasury Green Book. TAG Unit 2.7.1, in: http://www.dft.gov.uk/webtag/documents/index.php, retrieved 10 November 2013.

Deutsche Bahn (1995a), Projekt „Stuttgart 21“. Die Machbarkeitsstudie, Stuttgarter Druckerei: Stuttgart.

Deutsche Bahn (1995b), Das Synergiekonzept Stuttgart 21. Die Ergebnisse des Vorprojekts, Stuttgarter Druckerei: Stuttgart.

Deutsche Bahn (2013a), Pressekonferenz Stuttgart 21 vom 5. März 2013, in: http://www.bahnprojekt-stuttgart-ulm.de/mediathek/detail/download/aufsichtsratbeschluesse-der-db-ag-zu-s21-vom-5-maerz/mediaParameter/download/Medium, retrieved 10 November 2019.

Deutsche Bahn (2013b), Planänderung für das Grundwassermanagement in den Planfeststellungsabschnitten 1.1, 1.5, 1.6a, Stuttgart.

Deutsche Bahn (2018), Aufsichtsrat der Deutschen Bahn AG hat über Termin- und Kostenentwicklung von Stuttgart 21 und der Neubaustrecke Wendlingen-Ulm beraten, retrieved 15 April 2020.

Deutscher Bundestag (2013), Verkehrsinvestitionsbericht für das Berichtsjahr 2011, Drucksache 17/12230.

Dunleavy, P. (1991), Democracy, Bureaucracy and Public Choice, Hemel Hempstead: Harvester Wheatsheaf.

Eisenbahn-Bundesamt (2010), Planfeststellungsbeschluss gemäß § 18 AEG für das Vorhaben NBS/ABS Nürnberg-Ingolstadt-München Ausbaumaßnahmen im Bereich Reichertshofen Planungsabschnitt $12 \mathrm{M}$ der Ausbaustrecke Ingolstadt-München Strecken-Nr. 5501 Bahn-km 74,213 - 70,750 (-70,650), in: www.eba.bund.de, retrieved 10 November 2019.

Eisenbahn-Bundesamt (2012), Richtlinien für den Erlass planungsrechtlicher Zulassungsentscheidungen für Betriebsanlagen der Eisenbahnen des Bundes nach $\S 18$ AEG sowie für Betriebsanlagen von Magnetschwebebahnen nach § 1 MBPIG, in: http://www.eba.bund.de/SharedDocs/Publikationen/DE/PF/Planfeststellung/23_pf_richt linien.html, retrieved 10 November 2019.

Faludi, A. (1973), Planning theory, Pergamon Press: New York.

Flyvbjerg, B. (1998), Rationality and power: Democracy in practice, University of Chicago Press: Chicago.

Flyvbjerg, B. (2007), "Cost overruns and demand shortfalls in urban rail and other infrastructure", Transportation Planning and Technology, Vol. 30 No. 1, pp. 9-30.

Flyvbjerg, B. (2009), "Survival of the unfittest: why the worst infrastructure gets built - and what we can do about it", Oxford Review of Economic Policy, Vol. 25 No. 3, pp. 344367.

Flyvbjerg, B.; Bruzelius, N. and Rothengatter, W. (2003a), Megaprojects and Risk: An Anatomy of Ambition, $8^{\text {th }}$ edition, Cambridge University Press: Cambridge.

Flyvbjerg, B. and COWI (2004), Procedures for Dealing with Optimism Bias. Transport Planning: Guidance Document, UK Department for Transport: London.

Flyvbjerg, B.; Skamris Holm, M.K. and Buhl, S.L. (2002), "Underestimating cost in public works. Error or Lie?”, Journal of the American Planning Association, Vol. 68 No. 3, pp. 279-295.

Flyvbjerg, B.; Skamris Holm, M.K. and Buhl, S.L. (2003b), "How common and how large are cost overruns in transport infrastructure projects?", Transport Reviews, Vol. 23 No. 1, pp. 71-88. 
Flyvbjerg, B.; Skamris Holm, M.K. and Buhl, S.L. (2004), "What causes cost overrun in transport infrastructure projects?", Transport Reviews, Vol. 24 No. 1, pp. 3-18.

Fouracre, P.R.; Allport, R.J. and Thomson, J.M. (1990), The performance and impact of rail mass transit in developing countries, Crowthorne, Berkshire, Transport and Road Research Laboratory.

Hall, P. (1980), Great Planning Disasters, Penguin Books: Harmondsworth.

Han, S.H.; Yun, S.; Kim, H.; Kwak, Y.H.; Park, H.K. and Lee, S.H. (2009), “Analyzing schedule delay of mega project: lessons learned from Korea train express". IEEE Transactions on Engineering Management, Vol. 56 No. 2, pp. 243-256.

Holzhey, M. (2010), Schienennetz 2025/2030 - Ausbaukonzeption für einen leistungsfähigen Schienengüterverkehr in Deutschland, in: Umweltbundesamt 42/2010, Dessau-Roßlau.

Isenberg, M. (2008), Zuschüsse für Stuttgart 21 - Flughafen hilft Bahn auf die Beine. „Flughafen hilft Bahn auf die Beine“, in: http://content.stuttgarternachrichten.de/stn/page/detail.php/1793028/r_article_print, retrieved 10 November 2013.

Kahneman, D. (1994), "New challenges to the rationality assumption", Journal of Institutional and Theoretical Economics, Vol. 150 No. 1, pp. 18-36.

Kahneman, D. and Lovallo, D. (1993), "Timid choices and bold forecasts: A cognitive perspective on risk taking", Management Science, Vol. 39 No. 1, pp. 17-31.

Kahneman, D. and Tversky, A. (1979a), "Prospect theory: an analysis of decisions under risk", Econometrica, Vol. 47, pp. 263-292

Kahneman, D. and Tversky, A. (1979b), Intuitive Prediction: Biases and Corrective Procedures., In: Makridakis S.; Wheelwright S. C.(Ed.s), Studies in the Management Sciences: Forecasting, 12th edition, Amsterdam: North Holland.

Kefer, V. (2010), Siebte Fachschlichtung. Kosten und Finanzierung S21, in: http://www.bahnprojekt-stuttgartulm.de/uploads/tx_smediamediathek/S21_KostenUndFinanzierung.pdf, retrieved 10 November 2019.

Kefer, V. (2012), Stuttgart 21 und NBS Wendlingen-Ulm Unterlage für den Prüfungs- und Complianceausschuss (PCA) der DB und den Lenkungskreis (LK) S21, retrieved 10 November 2019.

Kommunikationsbüro Bahnprojekt Stuttgart (2009), Projektpartner sind sich einig: Stuttgart 21 kommt, Stuttgart.

Kostka, G.; Anzinger, N. (2016), Large Infrastructure Projects in Germany: A Cross-sectoral Analysis. In: Kostka, G.; Fiedler, J. (Ed.s) Large Infrastructure Projects in Germany. Palgrave Macmillan, Cham.

LaFollette, H. (2013), The Blackwell Guide to Ethical Theory, 2nd edition, Blackwell: Oxford.

Land Baden-Württemberg, Landeshauptstadt Stuttgart, Verband Region Stuttgart, Flughafen Stuttgart GmbH, DB Netz Aktiengesellschaft, DB Station\&Service Aktiengesellschaft, DB Energie GmbH, Deutsche Bahn Aktiengesellschaft (2009), Finanzierungsvertrag Stuttgart 21, Stuttgart.

Lavallo, D. and Kahneman, D. (2003), "Delusions of success - how optimism undermines executives' decisions”, Harvard Business Review, Vol. 81 No. 7, pp. 56-63, 117.

Lee, C.L.; Robinson, J. and Reed, R. (2008), "Listed property trusts and downside systematic risk sensitivity", Journal of Property Investment \& Finance, Vol. 26 No. 4, pp. 304328. 
Lee, J.K. (2008), "Cost overrun and cause in Korean social overhead capital projects: roads, rails, airports, and ports", Journal of Urban Planning and Development, Vol. 134 No. 2 , pp. 59-62.

Mackie, P. and Preston, J. (1998), "Twenty-one sources of error and bias in transport project appraisal", Transport Policy, Vol. 5 No. 1, pp. 1-7.

Morris, P. and Hough, G.H. (1987), The Anatomy of Major Projects: A Study of the Reality of Project Management, John Wiley and Sons: New York.

Morris, S. (1990), "Cost and time overruns in public sector projects", Economic and Political Weekly, Vol. 15 No. 47, pp. 154-168.

Nijkamp, P. and Ubbels, B. (1999), "How reliable are estimates of infrastructure costs? A comparative analysis", International Journal of Transport Economics, Vol. 26 No. 1, pp. 23-53.

Noreen, E. (1988), "The economics of ethics: a new perspective on agency theory", Accounting Organisations and Society, Vol. 13 No. 4, pp. 359-369.

Odeck, J. (2004), “Cost overruns in road construction?”, Transport Policy, Vol. 11 No. 1, pp. 43-53.

Pickrell, D. (1990), Urban rail transit projects: forecast versus actual ridership and cost, Washington D.C., US Department of Transportation.

Pickrell, D. (1992), “A desire named streetcar. Fantasy and fact in rail transit planning", Journal of the American Planning Association, Vol. 58 No. 2, pp. 158-176.

Sing, T. and Ong, S. (2000), "Asset allocation in a downside risk framework", Journal of Real Estate Portfolio Management, Vol. 6 No. 3, pp. 213-223.

Singh, R. (2010), "Delays and cost overruns in infrastructure projects: extent, causes and remedies", Economic and Political Weekly, Vol. 45 No. 21, pp. 43-54.

Statistisches Bundesamt (2013a), Produktionsindex für das Bauhauptgewerbe - Tiefbau, in: www.destatis.de, retrieved 10 November 2019.

Statistisches Bundesamt (2013b), Gemeindeverzeichnis - Gebietsstand: 30.09.2013 (3. Quartal), in: www.destatis.de, retrieved 10 November 2013.

Trans-European Transport Network (2010), Priority Projects 2010. A detailed Analysis, in: http://ec.europa.eu/transport/themes/infrastructure/ten-t-implementation/priorityprojects, retrieved 10 November 2019.

Vieregg-Rössler (2008), Ermittlung der wahrscheinlichen Kosten des Projektes Stuttgart 21 (im Auftrag der Fraktion Bündnis 90 DIE GRÜNEN im Gemeinderat der Stadt Stuttgart und des BUND Landesverband Baden-Württemberg), München.

Wachs, M. (1982), "Ethical dilemmas in forecasting for public policy", Public Administration Review, Vol. 42 No. 6, pp. 562-567.

Wachs, M. (1987), "Forecasts in urban transportation planning: uses, methods and dilemmas", Climatic Change, Vol. 11, 61-80.

Wachs, M. (1989), "When planners lie with numbers", Journal of the American Planning Association, Vol. 55 No. 4, pp. 476-479.

Wachs, M. (1990), "Ethics and advocacy in forecasting for public policy", Business and Professional Ethic Journal, Vol. 9 No. 1-2, pp. 141-157.

Wurstbauer, D. and Schäfers, W. (2015), "Inflation hedging and protection characteristics of infrastructure and real estate assets", Journal of Property Investment \& Finance, Vol. 33 No. 1, pp. 19-44.

Zillante, A.; Read, D.C. and Seiler, M.J. (2019), "Using prospect theory to better understand the impact of uncertainty on real estate negotiations", Journal of Real Estate Research, Vol. 41 No. 1, pp. 75-105. 


\section{Tables and Figures}

Table I: Timeline of key events

\begin{tabular}{|c|c|}
\hline Date & Short description \\
\hline Apr 1994 & $\begin{array}{l}\text { Project "Stuttgart } 21 \text { " was officially presented at a press conference. The } \\
\text { completion is planed for } 2008 \text {. }\end{array}$ \\
\hline Jan 1995 & Feasibility study was presented. \\
\hline 1995 & $\begin{array}{l}\text { The preliminary concept was further analysed regarding technology } \\
\text { (geological and hydrological investigation) and economy. The economic } \\
\text { viability of the project was confirmed. }\end{array}$ \\
\hline Nov 1995 & $\begin{array}{l}\text { The framework agreement is signed by the federal government, the } \\
\text { railway company (Deutsche Bahn), the state, the region and the city for } \\
\text { the development and support of this project; cost estimate is } 4.893 \text { billion } \\
\text { Deutsch mark. }\end{array}$ \\
\hline Jun 1996 & Founding of S21 project company \\
\hline Jul 1996 & $\begin{array}{l}\text { The project commission recommended the further development of the } \\
\text { proposal submitted by Trojan, Trojan }+ \text { Neu for the urban redevelopment. }\end{array}$ \\
\hline Dec 1996 & $\begin{array}{l}\text { Deutsche Bahn opens the regional planning process and publishes the } \\
\text { relevant documentation for public inspection. }\end{array}$ \\
\hline Jul 1997 & $\begin{array}{l}\text { The municipal council passes the urban development framework plan; } \\
200 \text { of the } 900 \text { suggestions from the public hearing in June } 1997 \text { had been } \\
\text { included. }\end{array}$ \\
\hline Nov 1997 & $\begin{array}{l}\text { The design by Ingenhoven, Overdiek und Partner (Düsseldorf) won the } \\
\text { realisation competition for the new main station. }\end{array}$ \\
\hline Oct 1998 & $\begin{array}{l}\text { The new federal government (coalition of Social Democratic Party of } \\
\text { Germany and Alliance '90/The Greens) put off to progress the project. } \\
\text { Deutsche Bahn's chairman is opposed to Stuttgart } 21 \text {. The supervisory } \\
\text { board had postponed a decision on the progress six times until } 2000 \text {. }\end{array}$ \\
\hline 1999 & $\begin{array}{l}\text { Project stop by the Deutsche Bahn; project is too big to get realised by } \\
\text { the railway company. }\end{array}$ \\
\hline Nov 1999 & The new chairman of Deutsche Bahn restarts the project. \\
\hline Jul 2001 & $\begin{array}{l}\text { New framework agreement is signed. The city will buy the free space of } \\
\text { the terminus station for EUR } 459 \text { million }\end{array}$ \\
\hline Oct 2001 & The planning approval section (PfA) 1.1 begins. \\
\hline Jan 2002 & Change of the S21 project manager: Peter Marquart \\
\hline Jan 2005 & PfA 1.1 receives the building permit. \\
\hline Jul 2007 & $\begin{array}{l}\text { Memorandum of understanding: contract partners confirm the purpose to } \\
\text { build S21 and the new line Wendlingen-Ulm; cost estimate is EUR } 2.8 \\
\text { bn. for S21. }\end{array}$ \\
\hline Nov 2007 & $\begin{array}{l}1^{\text {st }} \text { public petition: S21 opponents with the backing of the Green political } \\
\text { party (Greens) hand over } 67,000 \text { signatures to the city council, which }\end{array}$ \\
\hline
\end{tabular}




\begin{tabular}{|c|c|}
\hline & $\begin{array}{l}\text { should result in a referendum, in which the voters can decide whether the } \\
\text { project proceed. The city council rejected the citizens' request as } \\
\text { inadmissible. }\end{array}$ \\
\hline Apr 2008 & Change of the S21 project manager: Hany Azer \\
\hline Jul 2008 & $\begin{array}{l}\text { On behalf of the Greens and an environmental NGO (BUND), the } \\
\text { consultancy Vieregg + Rössler estimates the costs of up to EUR } 6.2 \text { bn. }\end{array}$ \\
\hline Apr 2009 & $\begin{array}{l}\text { Financing contract: Contract partners sign the financing agreement; cost } \\
\text { estimate is EUR } 3.076 \text { bn. plus a risk buffer of EUR } 1.45 \text { bn. }\end{array}$ \\
\hline Oct 2009 & For the first time, S21 opponents meet for a weekly demonstration. \\
\hline Feb 2010 & Official start of construction \\
\hline Aug 2010 & $\begin{array}{l}\text { Demolition of the north central station wing. Thousands demonstrate } \\
\text { against the demolition. }\end{array}$ \\
\hline Sep 2010 & $\begin{array}{l}\text { Demonstration: the police clears the park in front of the central stations } \\
\text { and seriously injured numerous demonstrators. }\end{array}$ \\
\hline Oct 2010 & $\begin{array}{l}2 \text { demonstrations with more than 50,000 participants each. Arbitration } \\
\text { process between the constructing partners and the citizens starts. }\end{array}$ \\
\hline Mar 2011 & $\begin{array}{l}2^{\text {nd }} \text { public petition: S21 opponents collect } 35,000 \text { signatures. The city } \\
\text { council rejected the citizens' request as inadmissible since it is not a city- } \\
\text { specific project. The Federal Administrative Court confirms the rejection. } \\
\text { Change of government; the coalition of the Greens and Social Democrats } \\
\text { achieve a majority in the state election. For the first time, the Greens has } \\
\text { appointed a prime minister in Germany. }\end{array}$ \\
\hline Jun 2011 & Change of the S21 project manager: Stefan Penn \\
\hline Jul 2011 & $\begin{array}{l}\text { The stress test, agreed in the arbitration process regarding the } \\
\text { performance of the central station, confirms the benefit. Deutsche Bahn } \\
\text { awarded contracts for the tunnels in PfA } 1.2 \text { and PfA } 1.6 \mathrm{a} \text {. }\end{array}$ \\
\hline Nov 2011 & $\begin{array}{l}\text { In a state-wide referendum, a majority votes against the exit of financing } \\
\text { S21. Voting results in details are: } 58.9 \% \text { state-wide and } 52.9 \% \text { in the } \\
\text { city of Stuttgart. }\end{array}$ \\
\hline Mar 2012 & $\begin{array}{l}\text { Delays: At the steering committee meeting, Deutsche Bahn announced } \\
\text { the commissioning for December } 2020 \text {. }\end{array}$ \\
\hline Dec 2012 & Deutsche Bahn announced a new cost estimate of up to EUR $6.5 \mathrm{bn}$. \\
\hline Feb 2013 & Opening of S21 is planned for 2021 \\
\hline Mar 2013 & Funding framework increased to EUR 6.5 bn. \\
\hline Sep 2013 & Change of the S21 project manager: Manfred Leger \\
\hline Dec 2013 & Construction work for the first tunnel starts. \\
\hline Sep 2014 & Construction work for the Filder tunnel starts. \\
\hline Dec 2014 & $\begin{array}{l}3^{\text {rd }} \text { public petition: S21 opponents collect } 20,000 \text { signatures. The city } \\
\text { council rejected the citizens' request as inadmissible since it is not a city- } \\
\text { specific project. }\end{array}$ \\
\hline Dec 2014 & $4^{\text {th }}$ public petition: $S 21$ opponents collect 20,000 signatures. \\
\hline Nov 2017 & Deutsche Bahn announced higher costs and a later opening. \\
\hline
\end{tabular}


Jan 2018 Deutsche Bahn announced a new cost estimate of up to EUR 8.2 bn; the opening is planned for 2025 .

Note: This table shows a selection of key events and millstones for S21. For more events and a more detailed description of the events, see https://www.bahnprojekt-stuttgart-

ulm.de/en/overview/timeline and https://pix.stuttgarter-zeitung.de/timeline/s21. 
Table II: Explanation of theories

\begin{tabular}{|c|c|c|}
\hline Causes & Theories & Studies \\
\hline \multirow{3}{*}{ Technical } & $\begin{array}{l}\text { Forecasting } \\
\text { (Armstrong, 2001) }\end{array}$ & $\begin{array}{l}\text { Kahneman and Lovallo (1993), Wachs } \\
(1982,1987,1990), \text { Flyvbjerg } \text { et al. }(1998, \\
\text { 2002, 2003) }\end{array}$ \\
\hline & $\begin{array}{l}\text { Planning } \\
\text { (Faludi, 1973) }\end{array}$ & $\begin{array}{l}\text { Pickrell (1990, 1992), Altshuler and } \\
\text { Luberoff (2003), Hall (1980) }\end{array}$ \\
\hline & $\begin{array}{l}\text { Decision-making } \\
\text { (Dunleavy, 1991) }\end{array}$ & Bruzelius et al. (2002) \\
\hline \multirow{2}{*}{ Economical } & $\begin{array}{l}\text { Neoclassical economics } \\
\text { (Pickrell, 1992) }\end{array}$ & $\begin{array}{l}\text { Pickrell (1992), Odeck (2004), Wachs } \\
(1982,1987,1990)\end{array}$ \\
\hline & $\begin{array}{l}\text { Rational choice } \\
\text { (Arrow, 1987; Coleman, 1992) }\end{array}$ & $\begin{array}{l}\text { Hall (1980), Flyvbjerg et al. }(1998,2002 \text {, } \\
\text { 2003) }\end{array}$ \\
\hline \multirow{3}{*}{ Psychological } & $\begin{array}{l}\text { Planning fallacy and optimism bias } \\
\text { (Kahneman and Tversky, 1979a) }\end{array}$ & $\begin{array}{l}\text { Kahneman and Lovallo (1993), Pickrell } \\
\text { (1992), Flyvbjerg et al. (1998, 2002, 2003), } \\
\text { Fouracre et al. (1990), Mackie and Preston } \\
\text { (1998) }\end{array}$ \\
\hline & $\begin{array}{l}\text { Prospect } \\
\text { (Kahneman and Tversky, 1979a) }\end{array}$ & $\begin{array}{l}\text { Kahneman and Lovallo (1993), Flyvbjerg et } \\
\text { al. }(1998,2002,2003)\end{array}$ \\
\hline & $\begin{array}{l}\text { Rational choice } \\
\text { (Becker, 1976) }\end{array}$ & Kahneman and Lovallo (1993) \\
\hline \multirow{3}{*}{ Political } & $\begin{array}{l}\text { Machiavellianism } \\
\text { (Byrne and Whiten, 1988; Christie } \\
\text { and Geis, 1970; Odeck, 2004) }\end{array}$ & $\begin{array}{l}\text { Flyvbjerg et al. (1998, 2002, 2003), } \\
\text { Bruzelius et al. (2002), Hall (1980), Wachs } \\
\text { (1982, 1987, 1989), Morris and Hough } \\
\text { (1987), Morris (1990), Pickrell (1992), } \\
\text { Nijkamp and Ubbels (1999), Odeck (2004) }\end{array}$ \\
\hline & $\begin{array}{l}\text { Agency } \\
\text { (Noreen, 1999) }\end{array}$ & $\begin{array}{l}\text { Wachs }(1982,1987,1990) \text {, Flyvbjerg et al. } \\
(1998,2002,2003) \text {, Arvan and Leite (1990) }\end{array}$ \\
\hline & $\begin{array}{l}\text { Ethical } \\
\text { (Wachs, 1982; LaFollette, 2013) }\end{array}$ & $\begin{array}{l}\text { Wachs }(1982,1987,1990) \text {, Flyvbjerg et al. } \\
(1998,2002,2003)\end{array}$ \\
\hline
\end{tabular}

Note: This table is mostly a reproduction of Cantarelli et al.'s (2010) Table 2. For more information, see Cantarelli et al. (2010). 
Table III: Descriptive statistics

\begin{tabular}{lccccc}
\hline & $\boldsymbol{N}$ & Min. & Max. & Mean & StD \\
\hline duration of proceedings (in days) & 64 & 323 & 4,960 & 1,125 & 901 \\
\hline track length (in km) & 64 & 0.6 & 42.15 & 8.36 & 9.25 \\
\hline \# of municipalities & 64 & 1 & 8 & 2.36 & 1.34 \\
\hline population density (per km ${ }^{2}$ ) & 64 & 29 & 4,468 & 858 & 1,153 \\
\hline total costs (in bn. Euros) & 25 & 0.15 & 6.17 & 1.07 & 1.38 \\
\hline
\end{tabular}

Note: This table shows the summary statistics (number of observations $(N)$, minimum, maximum, mean, and standard deviation $(\mathrm{StD})$ ) for the plan approval procedures (PfA). The dependent variable duration of a PfA is measured in days; the track length in kilometres; the number of municipalities (\# municipalities), which are involved in the PfA, are integers; the population density refers to the arithmetic mean of the population densities of all municipalities affected by the PfA and are measured in residents per $\mathrm{km}^{2}$; and the total costs relates to the total costs of the PfA in billion euros. duration, track length, and \# municipalities are obtained from the respective PfA; the population density is collected from the Federal Statistical Office (Statistisches Bundesamt, 2013b); and total costs is obtained from the current traffic investment report (Deutscher Bundestag, 2013). 
Table IV: Regression models

\begin{tabular}{|c|c|c|c|c|}
\hline \multirow{2}{*}{\multicolumn{2}{|c|}{ Explanatory variable }} & \multicolumn{3}{|c|}{ Dependent variable: $\ln ($ duration$)$} \\
\hline & & M1 & M2 & M3 \\
\hline \multicolumn{2}{|c|}{ Constant } & $\begin{array}{c}2.175 * * * \\
(3.102)\end{array}$ & $\begin{array}{l}6.353 * * * \\
(7.183)\end{array}$ & $\begin{array}{l}5.998 * * * \\
(6.785)\end{array}$ \\
\hline \multicolumn{2}{|c|}{ In(track length) } & - & $\begin{array}{l}-0.1177 \\
(-1.294)\end{array}$ & $\begin{array}{l}0.0206 \\
(0.207)\end{array}$ \\
\hline \multicolumn{2}{|c|}{$\ln (\#$ of municipalities) } & - & $\begin{array}{c}0.4315^{* *} \\
(2.285)\end{array}$ & $\begin{array}{l}0.2006 \\
(1.103)\end{array}$ \\
\hline \multicolumn{2}{|c|}{ In(population density) } & - & $\begin{array}{c}0.1944 * * * \\
(2.953)\end{array}$ & $\begin{array}{l}0.0824 \\
(1.209)\end{array}$ \\
\hline \multirow{9}{*}{ 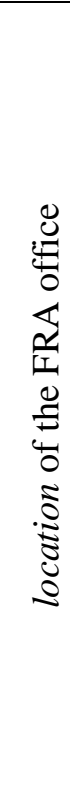 } & Berlin & - & $x_{1}$ & $\begin{array}{l}0.0259 \\
(0.108)\end{array}$ \\
\hline & Dresden & - & - & $\begin{array}{l}-0.3159 \\
(-0.867)\end{array}$ \\
\hline & Erfurt & - & - & $\begin{array}{l}-0.6717 * \\
(-1.970)\end{array}$ \\
\hline & Frankfurt/Saarbrucken & - & - & $\begin{array}{l}-0.2640 \\
(-1.110)\end{array}$ \\
\hline & Halle & - & - & $\begin{array}{l}-0.0156 \\
(-0.040)\end{array}$ \\
\hline & Hamburg/Schwerin & - & - & $\begin{array}{l}0,0065 \\
(0.023)\end{array}$ \\
\hline & Hannover & - & - & $\begin{array}{l}-0,3360 \\
(-1.187)\end{array}$ \\
\hline & Cologne & - & - & $\begin{array}{c}0.8963 * * * \\
(2.900)\end{array}$ \\
\hline & Munich & - & - & $\begin{array}{c}0.5101 * * \\
(2.127)\end{array}$ \\
\hline \multicolumn{2}{|c|}{$\ln ($ total costs $)$} & $\begin{array}{c}0.6877 * * * \\
(6.470)\end{array}$ & - & - \\
\hline \multicolumn{2}{|c|}{ Observations } & 25 & 64 & 64 \\
\hline \multicolumn{2}{|c|}{$\mathrm{R}^{2}$} & 0.645 & 0.159 & 0.460 \\
\hline \multicolumn{2}{|c|}{ adj. $R^{2}$} & 0.630 & 0.117 & 0.333 \\
\hline
\end{tabular}

Note: The dummy variable location captures the location of the responsible office of the Federal Railway Authority (FRA); they take the value of 1 if the respective office was responsible for a PfA and otherwise 0. The office located in Karlsruhe/Stuttgart is the base. All other variables are defined in Table III. The values in brackets stand for the $t$-values of the corresponding coefficients. $(* * *),(* *)$, and $(*)$ denote that the coefficients are significant at the $1 \%, 5 \%$, and $10 \%$ level, respectively. 
Table V: Estimated results for S21

\begin{tabular}{lccccccc}
\hline & & Actual & Actual & \multicolumn{2}{c}{ M1 } & \multicolumn{2}{c}{ M2 } \\
PAS & Beginning & $\begin{array}{c}\text { Estimated } \\
\text { (in days) }\end{array}$ & $\begin{array}{c}\text { Estimated } \\
\text { date }\end{array}$ & $\begin{array}{c}\text { Estimated } \\
\text { duration } \\
\text { (in days) }\end{array}$ & $\begin{array}{c}\text { Estimated } \\
\text { decision } \\
\text { date }\end{array}$ & $\begin{array}{c}\text { duration } \\
\text { (in days) }\end{array}$ & $\begin{array}{c}\text { decision } \\
\text { date }\end{array}$ \\
\hline 1.1 & $10 / 31 / 2001$ & 1,185 & $01 / 28 / 2005$ & 4,326 & $09 / 04 / 2013$ & 1,218 & $03 / 01 / 2005$ \\
\hline 1.2 & $12 / 17 / 2001$ & 1,341 & $08 / 19 / 2005$ & 4,326 & $10 / 21 / 2013$ & 918 & $06 / 22 / 2004$ \\
\hline 1.3 & $10 / 02 / 2002$ & \multicolumn{2}{c}{ ongoing } & 4,326 & $08 / 06 / 2014$ & 1,155 & $11 / 30 / 2005$ \\
\hline 1.4 & $06 / 14 / 2002$ & 2,147 & $04 / 30 / 2008$ & 4,326 & $04 / 18 / 2014$ & 1,805 & $05 / 23 / 2007$ \\
\hline 1.5 & $04 / 15 / 2002$ & 1,642 & $10 / 13 / 2006$ & 4,326 & $02 / 17 / 2014$ & 889 & $09 / 20 / 2004$ \\
\hline $1.6 \mathrm{a}$ & $08 / 30 / 2002$ & 1,720 & $05 / 16 / 2007$ & 4,326 & $07 / 04 / 2014$ & 927 & $03 / 13 / 2005$ \\
\hline $1.6 \mathrm{~b}$ & $06 / 18 / 2004$ & \multicolumn{2}{c}{ ongoing } & 4,326 & $04 / 22 / 2016$ & 1,383 & $03 / 31 / 2008$ \\
\hline
\end{tabular}

Note: This table compares the actual approval duration for the seven PfAs of S21 with the estimated duration using the coefficients of M1 and M2 (see Table IV). 
Figure 1: Maps of the project
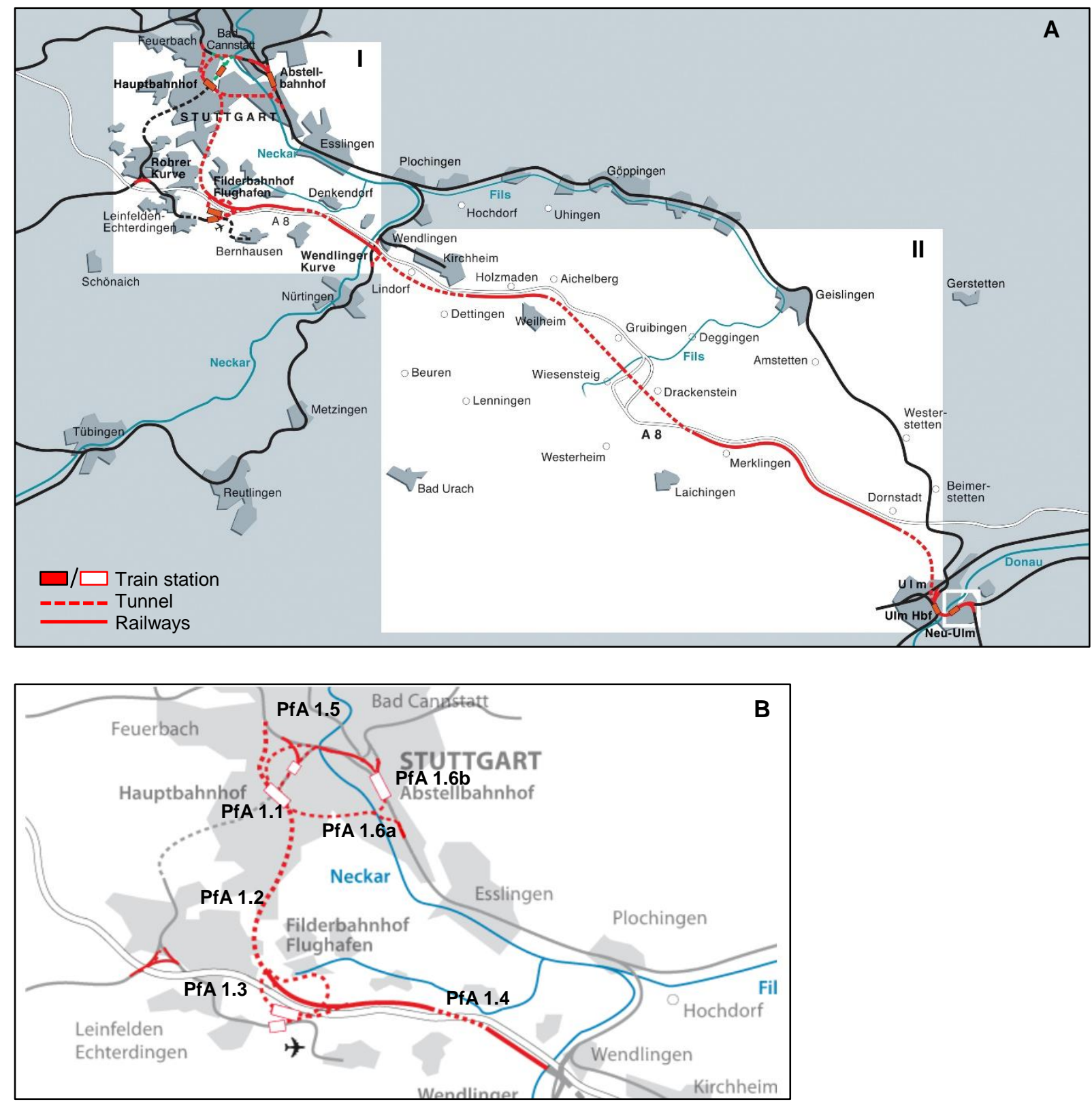

Note: Map A shows the entire route of the Stuttgart-Ulm railway project with sub-projects S21 of Stuttgart railway node (I) and NBS Wendlingen-Ulm line (II); Map B enlarges section I. Source: Deutsche Bahn (https://www.bahnprojekt-stuttgart-ulm.de/en/) 
Figure 2: Terminus vs. through station

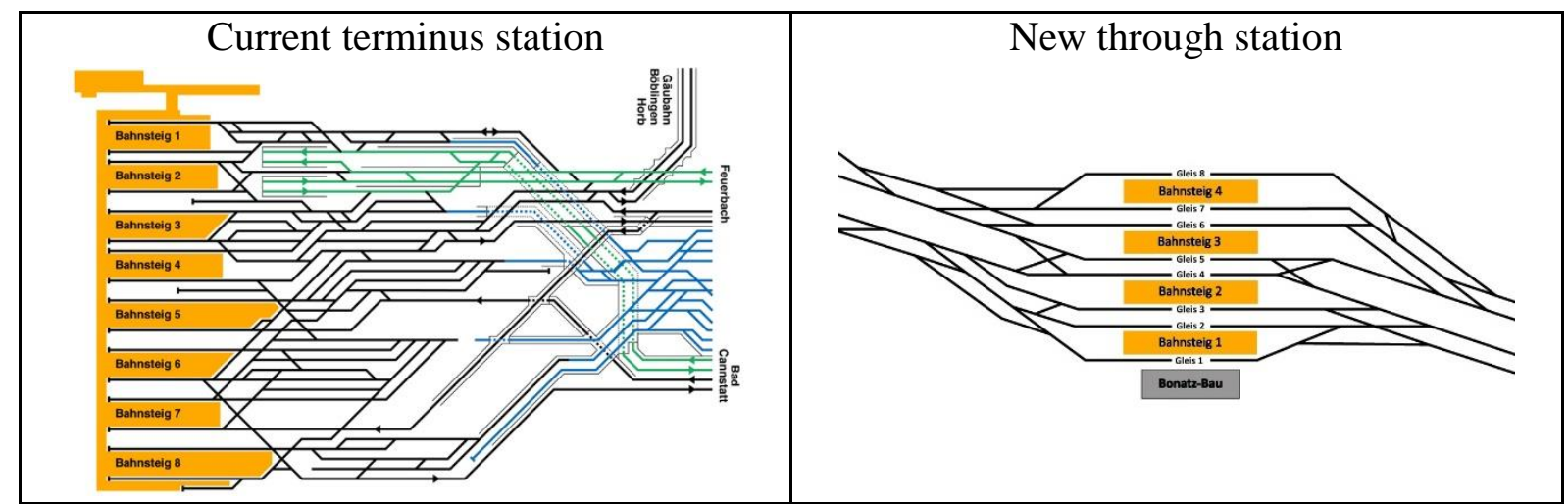

Note: This Figure shows the track layout of the current terminus station with 8 platforms (Bahnsteig) and 17 tracks in the left panel. The tracks partially block each other. This is solved by the layout of the new through station with 4 platforms (Bahnsteig) and 8 tracks (Gleis) in the right panel. Source: Deutsche Bahn (https://www.bahnprojekt-stuttgart-ulm.de/en/) 
Figure 3: Different discounting functions

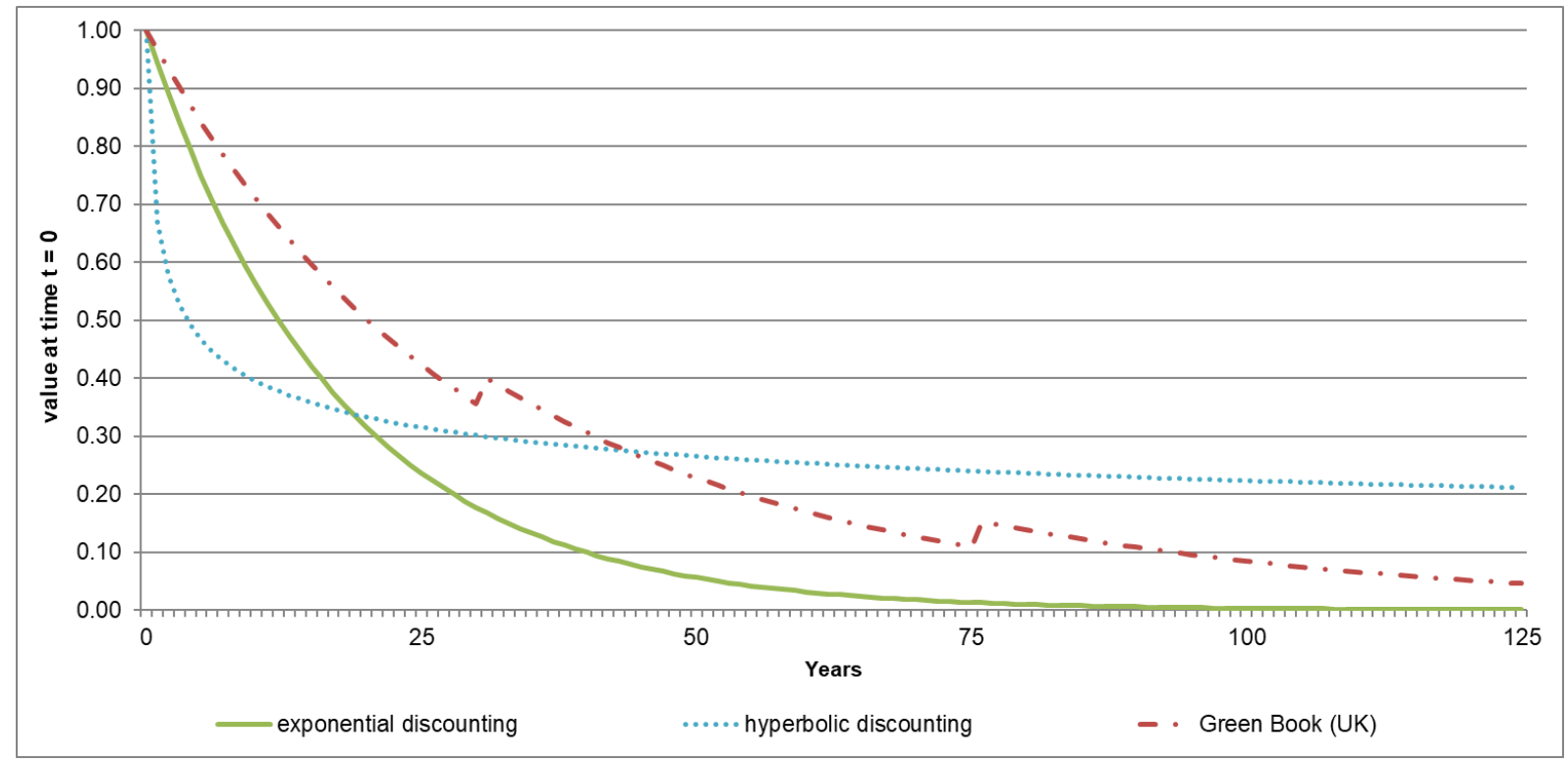

Note: This figure shows the classical exponential discount function with a time-constant discount rate and the hyperbolic functions. The parameters are from Angeletos et al. (2001). The last function is based on a stepwise exponential discount function as stated in the Green Book of the UK Department of Transportation (2011). 


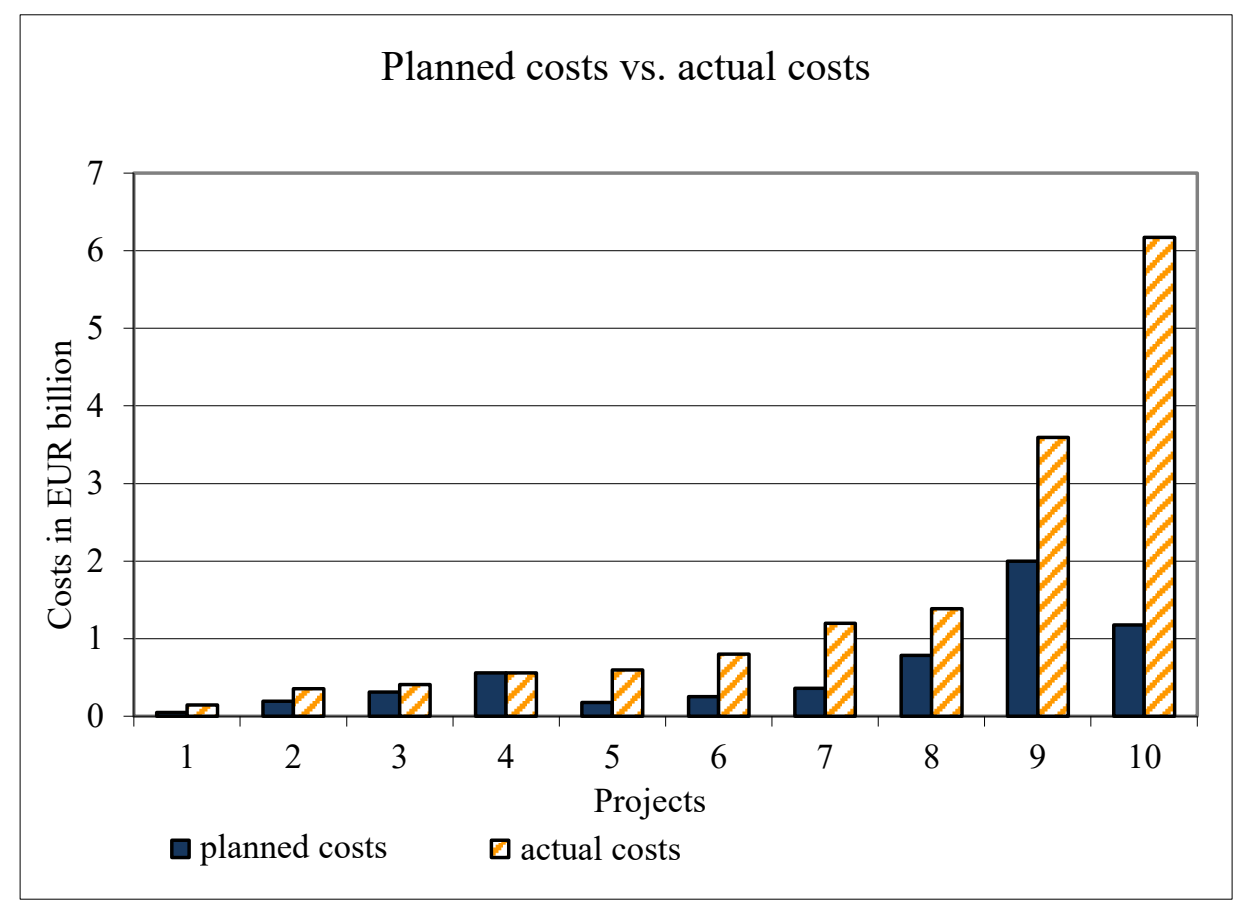

Note: This figure shows the planned costs and actual costs of 10 railway projects built by DB over the last years as reference projects. These are: 1) ABS KehlAppenweier (POS Süd), 2) ABS Stelle-Lüneburg, 3) ABS Paderborn-BebraErfurt-Weimar-Jena-Chemnitz, 4) ABS Oldenburg-Wilhelmshaven, 5) ABS Ludwigshafen-Saarbrücken (POS Nord), 6) ABS Berlin-Dresden, 7) Berlin HBF (Knoten Berlin), 8) ABS München-Mühldorf-Freilassing, 9) ABS/NBS Nürnberg-Ingolstadt-München, and 10) ABS/NBS Karlsruhe-OffenbachFreiburg-Basel. These projects are ascended ordered by their actual costs. Data are obtained from the transport investment report published by the Deutscher Bundestag (2013). 